\title{
PROFIL SURAT KABAR BATAK BERGERAK TAHUN 1941 DI TARUTUNG
}

\author{
Oleh: \\ Pulung Sumantri \\ Tiorumona Sihombing
}

\begin{abstract}
Abstrak
Penelitian ini bertujuan untuk mengetahui bagaimana latar belakang, pemasaran,tampilan dan desain,gambar dan iklan, serta tema berita yang menonjol dalam surat kabar Batak Bergerak tahun 1941 di Tarutung. Metode penelitian yang digunakan dalam penelitian ini adalah metode kepustakaan (Library Research) dengan jenis penelitian deskriptif kualitatif yang kemudian data/wacana tersebut dianalisa. Teknik pengumpulan data diambil dari buku-buku dan literatur yang berkaitan dengan surat kabar Batak Bergerak. Surat Kabar Batak Bergerak ini tidak terbit lagi sekarang, akan tetapi Pustaka Humaniora masih menyimpan surat kabar dan mendokumentasikannya. Penelitian ini menghasilkan bahwa yang melatar belakangi berdirinya suarat kabar Batak Bergerak adalah keinginan bangsa Indonesia untuk merdeka. Para intelektual yang menggabungkan diri dalam politik yang kemudian mendirikan surat kabar, yang nantinya digunakan untuk menyadarkan dan menanamkan keyakinan dalam mencapai kemerdekaan. Surat kabar ini berhaluan kebangsaan. Pemasaran surat kabar ini bukan hanya di Tarutung, tetapi sampai Sibolga, Sipirok, Sidempuan dan Silindung. Sasaran pemasaran surat kabar ini adalah orang-orang yang mampu baca tulis dan orangorang yang memiliki status sosial tinggi di masyarakat. Surat kabar Batak Bergerak di tulis dalam kertas A3 masing-masing halaman terdiri dari 5 kolom, dan bahasa yang digunakan dalam bahasa Indonesia dan Batak. surat kabar ini diterbitkan oleh Persaudaraan Batak di Tarutung dengan direktur Soetan Amir Hamzah. Setiap lembar awal surat kabar terdapat tulisan tahun terbit dan nama besar surat kabar. Dalam surat kabar ini ditemukan berbagai jenis iklan, yaitu: iklan sekolah, iklan niaga, iklan alat musik, iklan kopi, iklan rokok, iklan obat dan iklan pengumuman. Dalam surat kabar ini juga ditemukan artikel dan berita. Artikel tersebut terbagi dalam berbagai tema yaitu: persatuan, pengetahuan, politik dan agama. Berita juga terbagi dalam berbagai tema yaitu berita lokal, kriminal, duka cita dan Indonesia (Nasional) serta luar negeri.
\end{abstract}

Kata Kunci : Surat Kabar, Batak Bergerak. 


\section{PENDAHULUAN}

Sejak kedatangan Belanda ke Tapanuli banyak perubahan yang terjadi pada masyarakat Batak. Salah satunya adalah sistem pemerintahan. Sebelum kedatangan Belanda di Tapanuli belum mengenal yang namanya negara, setelah pengeruh Belanda maka yang awalny Huta Berubah menjadi Keresidenan. Yang awalnya orang Batak yang menganut sistem kepercayaan Animisme, berangsur-asur menganut agama Kristen. Dan sebelumnya agama Islam sudah berkembang di Tapanuli bagian selatan (Sipirok, dan Mandailing). Karena selain berdagang atau menerapkan sistem tanam paksa misi dari Belanda adalah menyebarkan agama Kristen. Hal ini dapat dilihat dari tujuan Belanda datang ke Indonesia yaitu 3G (Gold/kekayaan, Glory/kejayaan dan Gospel/injil).

Sejarah perkembangan pers di masa kolonial Belanda khususnya daerah Tapanuli pada masa kolonial Belanda, menjadikan sebuah awal dimasa lalu sebagai bentuk percetakan media massa pada zaman tersebut. Disisi lain sebagai bentuk perjuangan masyarakat pribumi melawan kolonialisme di zaman Hindia Belanda. Lahirnya kesadaran Nasional dan perjuangan kemerdekaan mengilhami orangorang untuk menerbitkan surat kabar dengan demikian menyebarkan gagasangagasan mereka.

Selama dalam masa perang atau pergerakan mempertahankan kemerdekaan, surat kabar adalah salah satu media massa yang mampu memberikan kontribusi atau peranan yang sangat besarbagi bangsa Indonesia khususnyadi Tapanuli. Peranannya sangat terlihat jelas dalam menyebarkan berita tentang perjuangan yang dapat membangkitkan semangat dan Nasionalisme rakyat.

Sejalan dengan perkembangan pengetahuan, awal terbit dan perkembangan pers di Indonesia pada umumnya dan Sumatera Utara pada khususnya sudah mengalami perjalanan yang cukup panjang. Pada awalnya pers diterbitkan oleh pemerintah Belanda akan tetapi tidak lama kemudian, orang Indonesia berhasil menerbitkan surat kabar milik anak negeri yang dilahirkan oleh para cendikiawan. 
Menurut Said (1976:285), ada 143 surat kabar dan majalah yang pernah terbit di Sumatera Utara pada massa1883-1942. Sembilan belas diantaranya terientifikasi terbit di Medan sebelum tahun 1930.

Perubahan yang terjadi di Tapanuli setelah di kuasai Belanda sangatlah besar dibidang Agama, Pembangunan, dan Intelektual (sekolah). Perubahan dalam bidang agama adalah sebagian besar orang Batak Toba menganut Agama Kristen. Dalam bidang pembangunan adalah dibukanya jalan-jalan kedaerah untuk memperlancar kegiatan perdagangan. Sedangkan dalam bidang intelektual adalah berdirinya sekolah-sekolah di Tapanuli. Para intelektual inilah yang nanti akan menggerakkan masyarakat untuk mengangkat senjata untuk mengusir penjajah.

Dalam menghadapi para penjajah, selain perjuangan bersenjata yang dilakukan oleh rakyat, para Intelektual yang bergabung dalam politik. Orang politik ini nantinya menggabungkan diri dengan surat kabar, surat kabar ini digunakan untuk menyadarkan dan menanamkan keyakinan dalam menuju tercapainya citacita kemerdekaan.

Surat kabar yang pernah terbit di Tapanuli adalah Suara Batak yang terbit pada tahun 1919 di Balige, Bintang Batak yang terbit pada tahun 1929 di Tarutung, kemudian menyusl Palito yang dipimpin Fridolina Panggabean, kemudian surat kabar Persatuan di pimpin oleh MH Manullang. Setelah surat kabar Persatuan dihentikan penerbitannya, maka terbitlah surat kabar Bendera Kita pada Tahun 1930-an di Tapanuli dan Batak Bergerak pada tahun 1941.

Dalam penelitian ini, metode yang digunakan adalah metode kepustakaan (Library Research) yaitu penelitian mencari data dalam perpustakaan, beberapa arsip, koran, dokumen dan buku-buku yang berkaitan dengan permasalahan yang akan diteliti dengan jenis penelitian deskriptif kualitatif yang kemudian data/wacana content tersebut dianalisa. Penelitian yang dilakukan terhadap koran dan dokumen menggunakan kritik sumber dengan mengeluarkan pendapat sendiri lalu melakukan penelitian terhadap isi dari surat kabar. 


\section{PEMBAHASAN}

\section{a. Sejarah Terbentuknya Surat Kabar Batak Bergerak}

Latar belakang surat kabar ini terbitkan oleh Persaudaraan Batak yang di directuri oleh Sutan Amir Hamzah adalah adanya keinginan para pendiri surat kabar untuk membentuk gerakan politik di di daerah kekuasaan Bataklanden. Sebenarnya dalam surat kabar ini sudah dijelaskan bahwa jauh sebelum surat kabar ini terbit sudah ada perkumpulan-perkumpulan politik di daerah ini, namun karena keras kepala dan ingin menang para anggota membuat perkumpulan ini tidak berkembang. Sehingga Sutan Amir Hamzah beserta para jajarannya mendirikan surat kabar ini sebagai fasilitas masyarakat untuk menyampaikan aspirasi dan mengajak para pemuda Bataklanden mendirikan perkumpulan Politik demi mencapai kemerdekaan.

Surat kabar Batak Bergerak terbit mingguan setiap hari Jum'at dengan menggunakan dua bahasa yaitu bahasa Indonesia dan Batak dan Bahasa Belanda sebagai bahasa tambahan. surat kabar ini termasuk suarat kabar berkala yang diterbitkan oleh para politisi yang menggabungkan diri dalam surat kabar.

\section{b. Pangsa Pasar Surat Kabar Batak Bergerak}

Surat Kabar Batak Bergerak di Tarutung didirikan oleh Sutan Amir Hamzah pada tahun 1941 bertujuan untuk mendirikan perkumpulan dan persatuan di daerah Bataklanden. Golongan - golongan yang menjadi sasaran surat kabar tersebut antara lain : (1) Orang Berpendidikan (Golongan golongan ini terdiri dari keturunan keturunan Indonesia yang pada umumnya merupakan bangsawan, tokoh terkemuka, atau pegawai negara dengan pendidikan minimal Hollandsch Inlandsche School (HIS) atau setara dengan pendidikan dasar). (2) Orang dengan Status Sosial (Orang orang yang memiliki status sosial sebagai bangsawan atau tetua adat sehingga dianggap sebagai golongan elite diantara keturunan keturunan asli Indonesia. Selain itu terdapat juga masyarakat yang bekerja sebagai pegawai negeri, dimana mereka bertugas untuk membantu pemerintahan yang sedang berkuasa hingga di pandang sebagai golongan dengan status sosial yang tinggi). 
Selain itu, pemasaran surat kabar Batak Bergerak bukan hanya masyarakat di sekitar Tarutung, tetapi sampai di Silindung, Sibolga, Padang Sidempuan dan Sipirok. Hal ini dapat dilihat dari iklan dan pemberitaan surat kabar.

\section{c. Format dan Tata Letak Surat Kabar Batak Bergerak}

Pada setiap awal surat kabar terdapat tulisan tahun terbit surat kabar. Tertera nama besar surat kabar bertulisan "BATAK BERGERAK". Adapun keterangan jelas dari pemrakarsa surat kabar adalah sebagai beriku:

- Pada bagian atas luar kolom surat kabar Batak Bergerak

Tengah atas luar kolom: tanggal, bulan dan tahun terbit surat kabar (nama bulan dan hari menggunakan Bahasa Indonesia).

Kiri paling atas luar kolom: terdapat nomor terbitnya surat kabar.

Kanan paling atas luar kolom: tahun terbitnya surat kabar contoh Tahun 1.

- Pada bagian tengan dalam kolom surat kabar:

Nama Surat kabar yaitu: Batak Bergerak dengan menggunakan huruf kapital dan ukuran hurufnya lebih besar dari yang lain dan juga dihitamkan (Bold).

Redaksi: B. Sihombing, Batara Saboe, A. Loemban Tobing

- Bagian kiri dalam kolom surat kabar:

Directure: Soetan Amir Hamzah

Alamat kantor : Taroetoeng

Telegram addres: Bergerak

Penerbit: Persaudaraan Batak

- Pada bagian kanan dalam kolom:

Pedagang: Justin Sihombing

Harga langganan : 60 ct. Sebulan

Pemasangan iklan: 30 cent/kolom atau berlangganan boleh berdamai.

\section{d. Iklan dalam Surat Kabar Batak Bergerak}

Gambar atau pun iklan yang ada dalam surat kabar Batak Bergerak. Dalam surat kabar ini terdapat gambar alat-alat musik seperti gitar, bass, piano dan lampu philips, serta ada gambar tokoh besi dalam iklan. Sedangkan iklan yang terdapat 
dalam surat kabar ini sangat banyak dengan tema yang berbeda-beda, seperti: iklan penerimaan murid baru disekolah (ini menunjukkan bahwa sejak dahulu pendidikan itu sangat penting), iklan niaga (berdagang adalah salah satu cara untuk memenuhi ekonomi), iklan alat musik (hal ini menunjukkan bahwa dalam ibadah agama kristen menggunakan alat musik), iklan kopi dan iklan rokok dan iklan tokoh obat serta iklan pengumuman.

\section{e. Artikel dan Berita}

Dalam surat kabar Batak Bergerak, penulis menemukan berbagai jenis artikel. Artike ini dapat dikelompokkan dalam berbagai tema yaitu: artikel persatuan ditemukan 9 artikel, artikel pengetahuan 9 artikel, artikel politik ditemukan 13 artikel, artikel agama ditemuka 5 artikel. Dan dalam surat kabar Batak Bergerak ini juga ditemukan berbagai jenis berita, yang dikelompokkan kedalam berbagai tema, yaitu: berita lokal ditemukan 5 artikel, berita kriminal 1 berita,berita duka cita ditemukan 2 berita, berita Nasional ditemukan 4 berita, sedangkan untuk berita Luar Negeri ditemukan 4 berita.

\section{PENUTUP}

Latar belakang surat kabar ini terbitkan oleh Persaudaraan Batak yang di directuri oleh Sutan Amir Hamzah adalah adanya keinginan para pendiri surat kabar untuk membentuk gerakan politik di di daerah kekuasaan Bataklanden. Sutan Amir Hamzah beserta para jajarannya mendirikan surat kabar ini sebagai fasilitas masyarakat untuk menyampaikan aspirasi dan mengajak para pemuda Bataklanden mendirikan perkumpulan Politik demi mencapai kemerdekaan.

Pangsa pasar dan pembaca surat kabar Batak Bergerak adalah orang-orang yang dapat baca tulis, yang terdiri dari keturunan keturunan Indonesia yang pada umumnya merupakan bangsawan, tokoh terkemuka, atau pegawai negara dengan pendidikan minimal Hollandsch Inlandsche School (HIS) atau setara dengan pendidikan dasar. Dan Orang orang yang memiliki status sosial sebagai bangsawan atau tetua adat sehingga dianggap sebagai golongan elite diantara keturunan keturunan asli Indonesia. 
Bentuk atau tampilan dan desain surat kabar Batak Bergerak yaitu pada bagian surat kabar sebelah kiri terdapat nama direktur, alamat telegram dan penerbit, sedangkan tengah atas terdapat tulisan nama surat kabar dengan tulisan besar dan bercetak tebal, dibawah nama surat kabar tertera nama-nama redaktur. Sebalah kanan bagian kepala surat kabar terdapat nama karyawan dan pengantar surat untuk orang-orang yang sudah berlangganan, dan tertera harga berlagganan serta harga pembuatan iklan. Bagian paling atas kepala surat kabar terdapat nomor terbit surat kabar, hari, tanggal, bulan dan tahun serta tahun terbitan.

Gambar atau pun iklan yang ada dalam surat kabar Batak Bergerak. Dalam surat kabar ini terdapat gambar alat-alat musik seperti gitar, bass, piano dan lampu philips, serta ada gambar tokoh besi dalam iklan. Sedangkan iklan yang terdapat dalam surat kabar ini sangat banyak dengan tema yang berbeda-beda, seperti: iklan penerimaan murid baru disekolah, iklan niaga, iklan alat musik, iklan kopi dan iklan rokok dan iklan tokoh obat serta iklan pengumuman.

Artikel dalam surat kabar ini sangat beragam temanya yaitu: Persatuan, Pengetahuan, Politik, dan agama. Dan tema berita dalam surat kabar ini juga sangat beragam yaitu tema pemberitaan lokal, kriminal, duka cita, berita Indonesia (nasional) dan berita luar negeri.

\section{Referensi}

Adam, Ahmad. (2003). Sejarah Awal Pers dan Kebangkitan Kesadaran Keindonesiaan. Yogyakarta: PT. Pustaka Pelajar.

Castles, Lance.(2001). Kehidupan Politik Suatu Keresidenan Di Sumatera: TAPANULI 1915-1940. Jakarta: Kepustakaan Populer Gramedia.

Kozok, Uli. (2010). Utusan Damai di Kemelut Perang: Peran Zending Dalam Perang Toba. Jakarta: Yayasan Pustaka Obor.

Nurdin.(2004). Sistem Komunikasi Indonesia. Jakarta:PT. Raja Grafindo Persada.

Said, Muhammad. ( 1976). Sejarah Pers Di Sumatera Utara Dengan Masyarakat Yang Dicerminkannya (1885-Maret-1942).

Said, Trimbun. (1988). Sejarah Pers Nasional dan Pengembangan Pers Pancasila. CV Haji Masagung: Jakarta.

Sjamsuddin, Helius . (2012). Metodologi Sejarah. Ombak: Yogyakarta.

TWH, Muhammad dan Qamar. 2013. Sejarah Pers Sumut dan Pendidikan Dasar Perfilman/Sinetron. Yayasan Museum Pers Sumut:Medan

Dokumentasi Koran Surat Kabar Batak Bergerak di tarutung 1941. 